\title{
The Impact of Entrepreneurial Orientation of Social Entrepreneurship Towards Social Capital and Organization Performance: A Case Study Of Precious One
}

\author{
Vera Andriana Rakhmani ${ }^{1 *}$, Risa Bhinekawati ${ }^{2}$ \\ ${ }^{12}$ Sekolah Tinggi Manajemen IPMI, DKI Jakarta 12750, Indonesia
}

\begin{abstract}
A B S T R A C T
Social enterprise which empowers disabilities is growing in Indonesia but research in this area is still lacking. Precious One ("P-One") is one of them. Started as a non-profit organization, P-One has been successfully converting itself into a profitable social enterprise. This study is fully focused on P-One because there's concern from the founder on the organization performance, where even though they are growing and profitable, it's not as fast as they are expected. This study aims to investigate the impact of social entrepreneurship and social capital on the organizational performance and to provide recommendation to the founder. The study employed mixed-method sequential explanatory strategy. This approach is performed by exercising quantitative method and followed by qualitative method. The data were gathered through questionnaires and interviews, and were then examined to see the causal relationship between defined variables by using Structural Equation Model (SEM). The research found that social entrepreneurship generates social capital among POne and its stakeholder, which then contributes to organizational performance. This study provides an understanding on the correlation between social entrepreneurship, social capital, and organization performance, especially for social enterprise which empowers disability. Social entrepreneurs, especially P-One founder will have better understanding of the key factors which will impact on their performance. Further study shall expand the sampling size and add more variables in the research to generate more precise result. Including financial measurement as an indication of organization's success would also be beneficial to give more accurate result.
\end{abstract}

ART ICLE INFO

\author{
Article History: \\ Received : 29-10-2019 \\ Revised : :11-02-2020 \\ Accepted : 19-02-2020 \\ Published : 30-06-2020
}

Keywords:

Social enterprise

social entrepreneurship

social capital

organization performance.

*Corresponding Author E-mail:

vera.rakhmani@ipmi.ac.id 


\section{INTRODUCTION}

Theodora, et al (2017) found that disabled community has become factual and significant part of the social community life. Based on SUPAS (Survei Penduduk Antar Sensus or Inter-census Population Survey) 2015 data, which was held by Indonesia Central Bureau of Statistics, 8.56 percent or 22 millions out of 225.18 millions of Indonesian population are disabled (BPS, 2015).

In Indonesia, the government and society has started to pay attention on the phenomena of social entrepreneurship and social inclusiveness, including the inclusion of disabled people in the workforce. Government has given the protection to the disabled population on having rights equality in obtaining a job by issuing Law No. 8 Year 2016 on Persons with disabilities, where Government or State-Owned Enterprise should employ minimum $2 \%$ of the total employees, and private companies should employ minimum $1 \%$ of the total employees.

This study was inspired by Precious One (P-One), founded in 2004 by Ratnawati Sutedjo, which was initially started as a foundation, now becoming a social enterprise dedicated to employing disable people. Its slogan is "Special Products for Special People", and their mission is to create job opportunity for disabilities by stimulating local production of high-quality crafts, such as visual aids, pillow, wallet, bags, pouch, necklace, toys, paper quilling, etc., and sell it to retail and corporate customers. By providing the job opportunity, disabled people are expected to become Independent and have purpose in life.

After more than 10 years, they are now serving many clients from domestic and international market. Some of their clients are well known companies, such as Fujifilm, Kalbe, Iwan Tirta, ANZ, JungleLand, Permata Bank, Halo BCA, Jakarta Great Sale, and Inasgoc for Asian Games 2018. P-One also always tries to open new opportunities in empowering more disabled people from other types of disabilities, such as intellectual and sight. They run "I Can Do" program, where these disabled people are packing spoon and tissue, targeting restaurants and catering services. This program is conducted as communitybased activity, in several workshops. Other than that, P-One also hosted several non-profit activities, such as Special Day for Special Children, Job Placement for Disabled People, Stop Bully Disabilities Campaign, and Everyone Can be a Hero.

Based on the interview with the founder, the company is now facing performance issue from the disabled employees, where in this context means the organization didn't grow as much as they wanted. In the last 3 (three) years, P-One still grow their net income and number of customers between $10-20 \%$. Their operational is no longer dependent on the donation. However, since the foundation shareholders expect higher growth rate, hey need to find a way to improve their organization performance. It is important to do this, since the bigger the organization, the bigger also the impact on the disabled community.

1. Since P-One is a social enterprise which is run by a social entrepreneur, the author would like to see whether the founder has reflected entrepreneurial orientation as part of her social entrepreneurship, and to see its relationship with social capital which is owned by P-One, and its organization performance. Accordingly, the research aims to investigate the impact of social entrepreneurship on social capital and organizational performance of $\mathrm{P}$ One.

To investigate the impact of social entrepreneurship on

\section{LITERATURE REVIEW \\ Social Entrepreneurship}

Not until recently, academic world has the interest in social entrepreneurship. According to Trivedi (2010) there are only little research in this area before 1989, which includes The Sociology of Social Movements written by J.A. Banks in 1972 and he Practice of Management written by $\mathrm{P}$. Drucker in 1979. The first introduced the term social entrepreneur and social entrepreneurship, while the latter introduced the social enterprise 
concept while advocating corporate ethical responsibilities.

Although social entrepreneurship is getting popular, there are a lot of confusion and uncertainties about this term since there is no exact definition on social entrepreneurship. There are many different concepts which were defined by many scholars.

Zahra etal. (2008) tried to extract the definition of social entrepreneurship from over than 20 definitions into simple definition, 'Social entrepreneurship encompasses the activities and processes undertaken to discover, define, and exploit opportunities in order to enhance social wealth by creating new ventures or managing existing organizations in an innovative manner' (p. 522).

Saifan (2012) proposed another concept where social entrepreneurship is an arena where entrepreneurs link their activities with social value creation as their final goal, with minimum intention of gaining personal profit (Saifan 2012). Saifan defined social entrepreneur as 'a missiondriven individual who uses a set of entrepreneurial behaviours to deliver a social value to the less privileged, all through an entrepreneurially oriented entity that is financially independent, self-sufficient, or sustainable'.

Another perspective comes from Tent (2015) in his journal, Social Entrepreneurship, which defined social entrepreneurship as a gathering of many business people with solid experience in the fields of management, finance and human relations sharing their know-how and experience along with money and ideas, in order to generate social welfare by removing some of the existing problems.

\section{Social Capital}

According to Adler and Kwon (2002), the social capital concept was classified into three group of definitions, which are external view, internal view, and integrated view between external and internal view. External view explains the relationship between social networks or among organizations. Internal view defines the relationship amongst individuals or groups. While the integrated view doesn't differentiate between internal and external aspects.

One of social capital definitions is coming from Trip et al. (2009), which stated that social capital may be defined as social networks, the norms of reciprocity and trust that arise from them, and the application of these assets in achieving mutual objectives. While OECD (2007) defined that social capital is networks together with shared norms, values and understandings that facilitate cooperation within or among groups. Another definition comes from Poteyeva (2019), which defines social capital as a concept in social science that involves the potential of individuals to secure benefits and inven $t$ solutions to problems through membership in social networks. Social capital revolves around three dimensions: interconnected networks of relationships between individuals and groups (social ties or social participation), levels of trust that characterize these ties, and resources or benefits that are both gained and transferred by virtue of social ties and social participation.

According to Fatoki (2011), a study on small and medium-sized enterprises in South Africa found that there was a significant positive relationship between human, social and financial capital on the organizational performance. Another research also shows the effect of social capital on many dependent variables, where social capital directly impacts organizational performance, growth, or effectiveness (Cheng et al., 2007; Sherman, 2007; Smerek and Denison; 2007; Bratkovic et al. 2009; Chisholm and Nielsen, 2009; Fatoki, 2011; Gupta et al., 2011; Roxas and Chadee, 2011).

\section{Organization Performance}

Organizational performance shows the status of organizational competencies. There are so many factors which need to be considered, since organizational performance can be seen from many perspectives. Mention a few includes market caps, sales growth, and sustainability. Not to forget how to determine where it should be resides, 
the individuals, team, business unit, or corporation as a whole.

Traditionally, organizational performance is associated with financial performance, such as profitability, sales, growth, return on investment, return on equity, and so on (Davis et al.,2010). However, financial results have its downside. They only reflect historical condition of an organization, which was the impact of past actions. Financial results cannot reflect future condition of an organization (Norreklit, 2000). To compliment the financial results, non-financial performance should also be factored in, such as customer satisfaction, internal process, and organization's innovation and improvement activities (Kaplan and Norton, 1992).

Mair \& Martí (2006) stated that the main concern of social enterprises is social value creation. The notion of "creating social value" which was developed by Porter \& Kramer (2011) explains a deeper relationship between business and society, as well as stronger motivation to develop social enterprises. 'Shared value creation focuses on identifying and expanding the connections between societal and economic progress' (Porter \& Kramer, 2011).

Wood \& Leighton (2010) defined social value refers to the wider non-financial impacts of programs, featuring organizations and interventions, including the wellbeing of individuals and communities, promotion of social capital, and protection of the surrounding environment, which are typically described as 'soft' outcomes. These outcomes are difficult to be quantified and measured.

Based on the literature reviews on social entrepreneurship, social capital, and organization performance, the framework theory which will be used for this research is shown in the following figure.

\section{Hypothesis Development}

In his study, Sookyuen Tepthong (2014) confirmed that social entrepreneurship has positive effect on social capital. His research showed the connection among social network and trust that are viewed as parts of social capital, and that social capital is strengthened by social entrepreneurship through social innovation activities, proactive behaviours, risk management.

H1: Social Entrepreneurship has positive and significant influence on social capital

Davis et al. (2010) found that organizations which prefer innovative, proactive, and risk-taking activities have more opportunity to compete with others. Basically, customers are more attracted in new products, services, and technologies, which may result in organizational growth. Social enterprises believe that they need to be innovative and proactive to thrive and grow in the market. Compared to passive organizations, proactive organizations can be seen as a leader which can

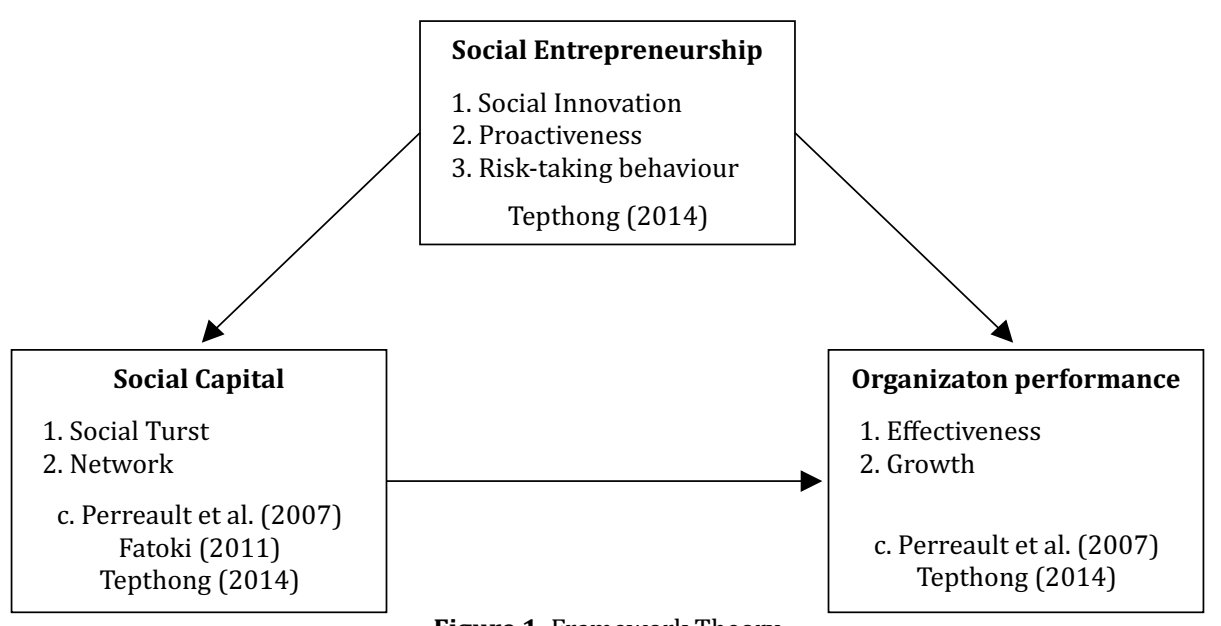

Figure 1. Framework Theory 
dominate the market.

H2: Social Entrepreneurship has positive influence on organization performance

The relationships between human capital, social capital, financial capital, and Small and Medium Enterprise (SME) performance were studied by Olawale Olufunso Fatoki in South Africa, in 2011, which one of the results was that social capital is positively associated with the SME performance (Fatoki, 2011). Furthermore, Chen et al. (2011), who studied the relationship between social capital, entrepreneurial orientation for new ventures, organizational resources for new ventures, and new venture performance, also confirming that there is positive relationship between social capital and new venture performance. Based on these studies, the following hypothesis for this research can be developed.

H3: Social capital has positive and significant influence on organization performance

Referring to those studies, the following variable in would like to be researched further in Precious One:

1. Social entrepreneurship

2. Social capital

3. Organizational performance

The conceptual framework of those variables is shown in the following figure.

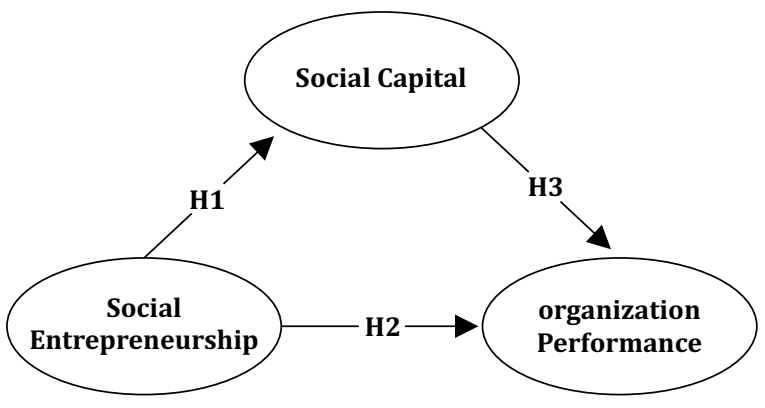

Figure 2. Conceptual Framework

\section{METHODS}

This research is using mixed-approach as the tool to gather necessary data for the study. Mixedmethod is an approach to collect, analyze, and integrate quantitative and qualitative data within a single study, with the purpose of obtaining better understanding of the problem (Tashakkori and Teddlie 2003; Creswell 2005). By combining both, qualitative and quantitative method, stronger analysis is expected to be obtained by taking advantage of the strengths of each method (Green, Caracelli, and Graham 1989; Miles and Huberman 1994; Green and Caracelli 1997; Tashakkori and Teddlie 1998).

Sequential explanatory design was selected by the author to complete the study. Ivankova et al. (2006) mentioned that amongst many mixed-methods methodology, sequential explanatory design is highly popular among researchers.

Sampling was usually taken since the population is considered too big to be researched, which will impact on the time, cost, and resources. However, since the population of the study object is considered small, then the author decided to use the whole P-One population (employees and owner) or commonly known as total population sampling. Total population sampling method is one of purposive sampling types, which is a nonprobability sampling method that is selected based on characteristics of a population and the objective of the study (Crossman, 2019).

For this mixed-method research, the author used two types of data, primary and secondary. To collect the data, the author prepared a questionnaire based on the variables and indicators that have been defined in chapter two of this thesis. The questionnaire was prepared in two forms, online and hard copy (direct administration). Online platform was used for collecting data from the normal P-One employees, and the hard copy was used for collecting data from the disabled P-One employees. Direct administration method was performed due to understanding issue. Respondents from disabled group has difficulty in understanding the question. Thus, a facilitated session was held for them, where they responded the questionnaires together at the same time. When they had question on particular questionnaire, the facilitator (one of 
the normal employees) could provide explanation or clarification. By having this facilitated session, the result is more accurate.

On top of that, the author also conducted short face-to-face interview with related stakeholders of P-One, which are the owner, one of the normal employees, one of the disabled employees, one of the partners which also acted as customers. This data is collected as qualitative data, which can provide better understanding on the business and context and validate the quantitative results.

Secondary data was also gathered to enrich the research, which includes journals, online documents, reports, and books.

The quantitative data analysis in this study is using Structural Equation Modelling (SEM). Structural equation models are complex, statistical models of linear relationships among latent (unobserved) variables and manifest (observed) variables (Sekaran and Bougie, 2016). According to Tepthong (2014), Hoyle (1995: 15) mentioned that the SEM approach is a more comprehensive method of research design than any other single statistical model. SEM approach provides more complex and specific testing.

This research in particular, is using Partial Least Square SEM (PLS SEM) method, which are able to process smaller data size and focuses on elaborating the variables during model examination (Hair et al. 2014).

There are several measurement and procedures for PLS-SEM analysis, which includes reliability and validity test, coefficient determination, and hypothesis testing.

As for qualitative approach, the data is collected from a direct, face-to-face interview with the respondents. Questions of the interview are made based on the survey questionnaire for the quantitative approach. The interview result is then summarized by each variable and indicators.

\section{RESULTS}

For quantitative approach, total respondents for quantitative data are 43 people, which are coming from P-One's environment. Most of the respondents are female, representing $77 \%$ of total respondents, while the remaining $23 \%$ population is male. The majority respondents are within the age group of 31-40 years old, represented by 15 people, followed by group age 18-30 years old with 13 people, $41-50$ years old with 10 people, and $>50$ years old with 1 person.

As for qualitative data, 4 female respondents were interviewed in a face-to-face session. Each person represents each stakeholder, to provide 360 degrees perspective. 4 people includes 1 owner, 1 normal employee, 1 disabled employee, 1 business partner who is also acts as customer.

\section{Quantitative Approach Result}

The reliability and validity test show that all variables, Social Entrepreneurship, Social Capital, and Organization Performance, shows Cronbach's alpha value more than $0,60(0,895 ; 0,690$; and 0,672 respectively). Referring to Sekaran and Bougie (2016) which stated that Cronbach's alpha value more than 0,6 is acceptable, we can conclude that all variables are reliable. Composite reliability test also shows that all variables are reliable since all constructs valued between 0.60 to 0.90 (Social Entrepreneurship 0,934; Social Capital 0,865; and Organization Performance $0,859)$.

Indicated by outer loading, which should have minimum value of 0,708 , all loading factors fulfilled the minimum value. It means all variables are reliable. This study is using Average Variance Extracted (AVE), which should have value above 0.50 . The test result for all variables show value above minimum requirement, which means all variables are valid.

Cross-loading correlation analysis is used in this research. To be considered as valid, an indicator's outer loadings should be greater than all of its loadings on the other constructs. 
Table 2. Discriminant Validity Result

\begin{tabular}{cccc}
\hline \multirow{2}{*}{ Indicator } & \multicolumn{3}{c}{ Variable } \\
\cline { 2 - 4 } & KS & MS & KP \\
\hline KSI & 0,889 & 0,475 & 0,586 \\
\hline KSP & 0,942 & 0,650 & 0,754 \\
\hline KSR & 0,894 & 0,542 & 0,625 \\
\hline MST & 0,449 & 0,848 & 0,564 \\
\hline MSN & 0,618 & 0,898 & 0,607 \\
\hline KPE & 0,653 & 0,562 & 0,870 \\
\hline KPG & 0,610 & 0,603 & 0,866 \\
\hline
\end{tabular}

Since all constructs are reliable and valid, the research model can be used to test the formulated hypotheses.

SEM-PLS method was used on the study to test the structural models, to see the coefficient of determination and path coefficient. This procedure was conducted to see the correlation significance between defined variables.

After knowing the correlation between variables, bootstrapping method was conducted to test the predefined hypotheses.

R-square value is a representative of determination coefficient. It assesses the suitability of the regression model by measuring how accurate the regression line projects the real data. To describe the R-square value, each of the variable value shall be multiplied by $100 \%$.

As stated in Table 3, the R-square value for social capital and organization performance are higher than $25 \%$, which means moderate. The R-square value of social capital is $38,3 \%$, where $38,3 \%$ of the variable variation can be explained by social entrepreneurship, while the remaining $61,7 \%$ shall be explained by other variables. While for organization performance, the coefficient of determination value is $60,9 \%$, where $60,9 \%$ of the variable variation can be explained by social entrepreneurship and the remaining 39,1\% shall be explained by other variables.

Table 1. Reliability \& Validity Test

\begin{tabular}{|c|c|c|c|c|c|}
\hline Variable & Indicator & Loading Factors & Cronbach's Alpha & Composite Reliability & Average Variance Extracted (AVE) \\
\hline \multirow[t]{3}{*}{ KS } & KSI & 0,889 & 0,895 & 0,934 & 0,826 \\
\hline & KSP & 0,942 & & & \\
\hline & KSR & 0,894 & & & \\
\hline \multirow[t]{2}{*}{ MS } & MST & 0,848 & 0,690 & 0,865 & 0,762 \\
\hline & MSN & 0,898 & & & \\
\hline \multirow[t]{2}{*}{ KP } & KPE & 0,870 & 0,672 & 0,859 & 0,753 \\
\hline & KPG & 0,866 & & & \\
\hline
\end{tabular}

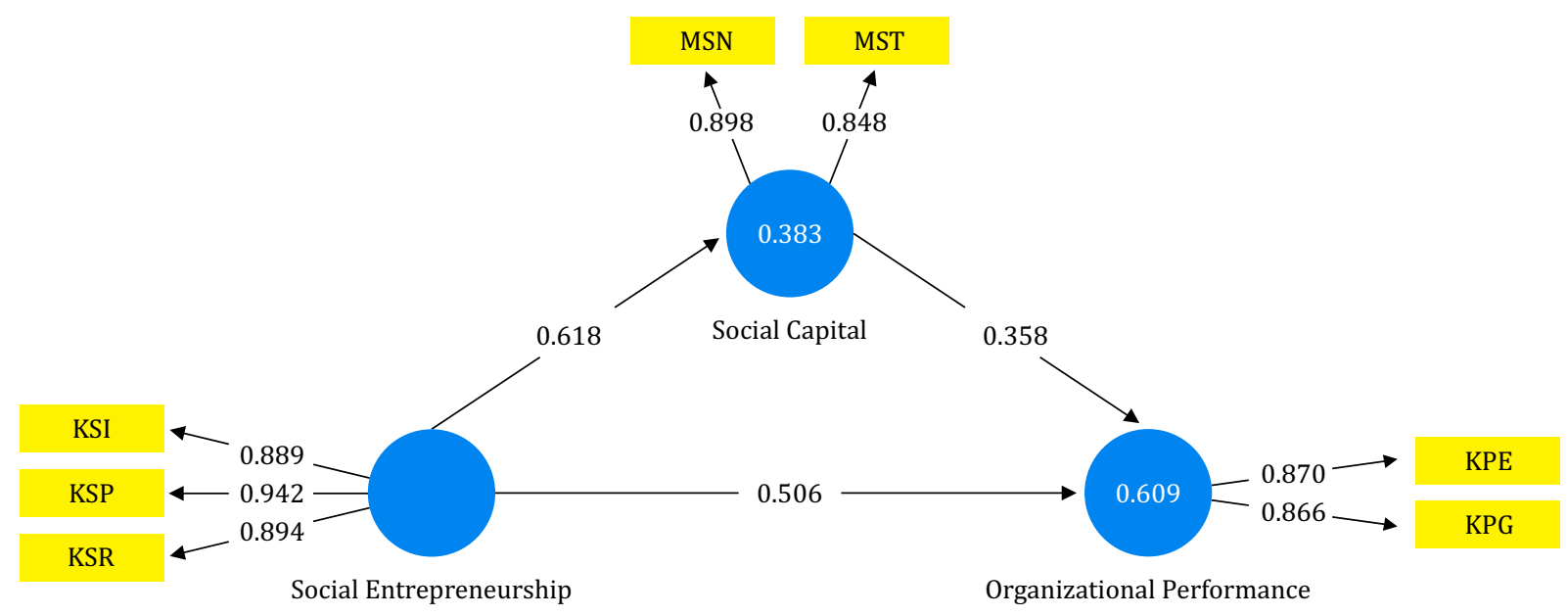

Figure 3. Coefficient Correlation Diagram 
Table 3. R-Square

\begin{tabular}{lc}
\hline \multicolumn{1}{c}{ Variable } & R-square \\
\hline Social Capital (MS) & 0,383 \\
\hline Organization Performance (KP) & 0,609 \\
\hline
\end{tabular}

There are two indicators of hypotheses testing measured in this research, T-test and P-Value, as showed in Table 4 below:

A hypothesis can be accepted if the generated value from the test is significant ( $\mathrm{t}$-statistic $>1,96$ and P-value $<0,005$ ), and on the other hand, a hypothesis is rejected if the generated value is not significant. Based on that statement, below is the hypotheses result based on the bootstrapping procedure:

1. H1: Social Entrepreneurship has influence on social capital

With positive original sample value, t-statistic 6,128 and p-value 0,000 , the hypothesis that social entrepreneurship has influence on social capital is accepted

2. H2: Social Entrepreneurship has influence on organization performance

With positive original sample value, t-statistic 3,654 and p-value 0,000 , the hypothesis that social entrepreneurship has influence on organization performance is accepted

3. H3: Social capital has influence on organization performance

With positive original sample value, t-statistic 2,685 and p-value 0,007, social capital has significant impact on organization performance, or in other words, this hypothesis is accepted

\section{Qualitative Approach Result}

The qualitative research is conducted to find the meanings of quantitative research. There are four (4) respondents which were invited to the indepth interviews, which are the founder (owner), one (1) normal employee representatives (ER1), one (1) disabled employee representatives (ER2), and one (1) partner which also acts as customer (PC). These people represent all 360-degree perspective for P-One.

All of the respondents have been informed on the purpose of the interview prior the interview sessions, and agreed that the given information during the interview would be recorded, transcribed, and used in this research.

All respondents are female, 50\% coming from the group age of $31-40$, and $75 \%$ has undergraduate

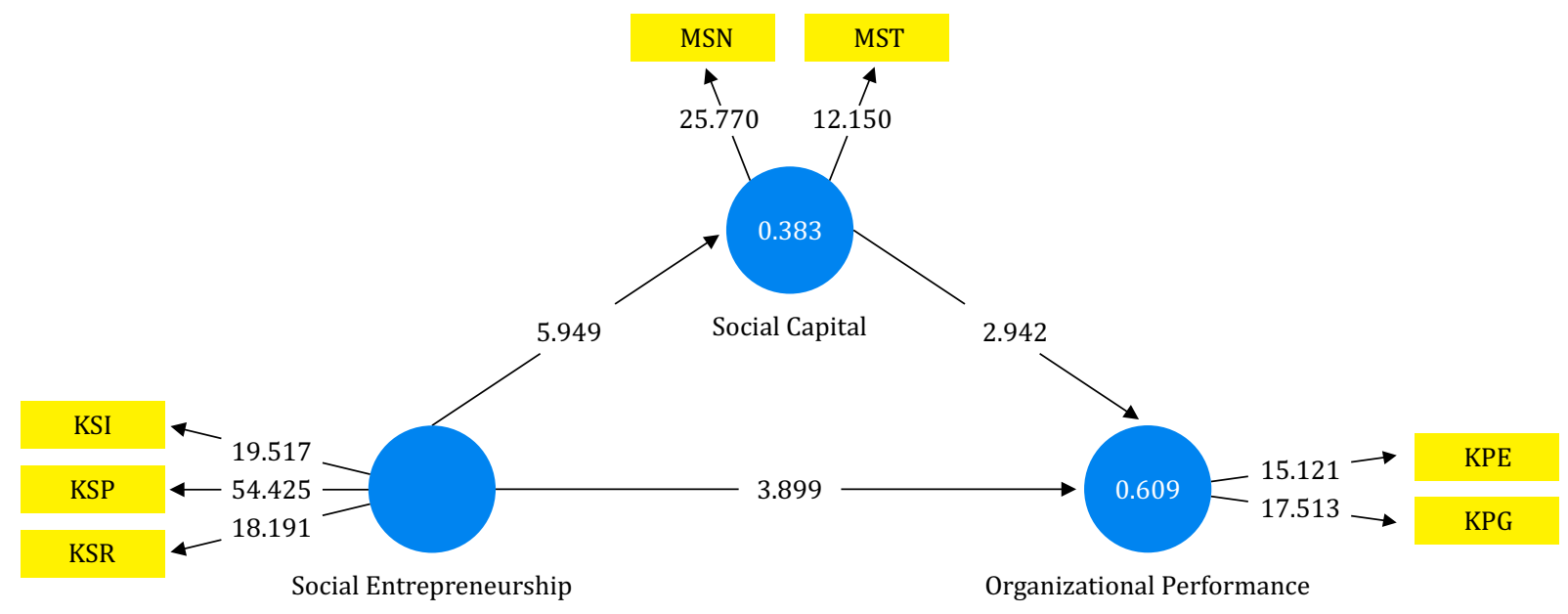

Figure 4. Significance diagram

Table 4. Path Coefficient

\begin{tabular}{lcccc}
\hline \multicolumn{1}{c}{ Variable Relations } & Original Sample (0) & T- Statistics & P-Value & Results \\
\hline Social Entrepreneurship -> Social Capital & 0,619 & 6,128 & 0,000 & Supported \\
\hline Social Entrepreneurship -> Organization Performance & 0,506 & 3,654 & 0,000 & Supported \\
\hline Social Capital -> Organization Performance & 0,358 & 2,685 & 0,007 & Supported \\
\hline
\end{tabular}


education background.

Key questions were related to the defined variables, social entrepreneurship, social capital, and organization performance, which were developed from the questionnaire questions.

1. Social entrepreneurship and social capital All respondents responded that P-One has reflected the value of being innovative, proactive, and willing to take risk in developing its business. One of the respondents, who representing partner/customer said:

"As a partner, happy to work with P-One since I'm able to share knowledge on Macramé and I get a lot of help from P-One as P-One can supply the products, so I can have ready-stock products."

By demonstrating social entrepreneurship values, P-One was quite successful in building its social capital. Their customers have good faith (socially trusted) and P-One has quite large networks to support their business.

2. Social entrepreneurship and organization performance

As mentioned before, innovation is not an issue in P-One. Consequently, innovation leads to higher staff quality, be it production and nonproduction. If required, production staff can be reallocated to a new project without difficulties, so P-One is not necessarily hiring new employee for it. As mentioned by one of the respondents:

"P-One has the ability to allocate their staff to work on special projects, such as Macramé. P-One production staff has several crafting skillset, so it's easy to switch between one project to another project."

By having people who have many skill-sets, the organization has the ability to improve their organization performance. Thus, social entrepreneurship has indirect influence to the organizational performance.

3. Social capital and organization performance Social trust, as one of the parts of social capital, is an important indicator for organization's well-being. Trust is related with organization commitment to their mission to the society, in this case specifically to the disability communities.

Trust also relates with network building. In the case of P-One, where they receive many repeat orders, they show that they are being trusted by their customer. During the interview, the owner mentioned:

"One of the indications is repeat order. Many customers keep repeating their order which means customers trust on P-One."

Networking helps P-One to get referrals from the existing customers, and broaden their existing network. By having more customers and network, P-One has the opportunity to expand their business and capabilities, which at the end will impact on the business growth.

\section{DISCUSSION}

The hypothesis testing resulted that social entrepreneurship has a positive impact on social capital. Further study showed that P-One reflected all elements of social entrepreneurship, which are innovative, proactive, and willing to take risk in developing itself. According to Tepthong (2014), the more existence of social entrepreneurship, the more social capital will be. Embracing social entrepreneurship, social entrepreneurs can create social capital activities such as social involvement and social network activities.

The interview also support the hypothesis. It showed that P-One takes benefit of network, be it for their own benefit to get more customers, or for its communities by partnering with other similar communities.

During his study, Sookyuen Tepthong (2014) provide the result that the relationship between social entrepreneurship and organizational performance doesn't have positive effect on organizational performance. In this study, on the contrary, this hypothesis was proven to be significant. Davis et al. (2010) found that organizations which prefer innovative, proactive, and risk-taking activities have more opportunity 
to compete with others. Basically, customers are more attracted in new products, services, and technologies, which may result in organizational growth. Social enterprises believe that they need to be innovative and proactive to thrive and grow in the market.

During the interview, all respondents agreed that P-One always try to be innovative, proactive, and risk-taker to improve its performance. Financially, their performance can be considered good, since their profit increased up to twenty percent in the last three years. However, it is hard to say that certain element is the key to organizational performance. Further research which involve bigger population and more variables might need to be done to get more accurate and detail result.

The testing result of this hypothesis showed that social capital does have significant influence on organization performance. P-One has obtained social trust and network, which have impacted on organization's success, even though it might not at the maximum result.

P-One needs to find a way to overcome their existing challenges (e.g. new products, price, and capacity) in order to improve their organization performance.

\section{CONCLUSION}

The objectives of this study-identifying the impact of social entrepreneurship on organizational performance, social entrepreneurship on social capital, and social capital to organizational performance-have been fulfilled.

The study used mixed-method sequential explanatory strategy. This approach is performed by exercising quantitative method and followed by qualitative method. The data was gathered through questionnaires and interviews. The questionnaire was involving 43 respondents, while the interviews were conducted on the POne stakeholders with 4 respondents to strengthen the questionnaire results.

The data which were gathered during survey was then examined to see the causal relationship between defined factors (social entrepreneurship, social capital, and organizational performance) by using Structural Equation Model (SEM). The test suggested that all factors fit the model.

The first objectives, identifying the impact of social entrepreneurship on social capital in P-One through social innovations, proactiveness, and risk-taking, has significant result. Based on this result, the conclusion is that the behaviours of social entrepreneurs can give impact on the trust and networking. Existing customers gained more trust on P-One's products and missions, then they make repetition orders. They also make good voice to others, which opens another opportunity for P-One from new customers.

The second objectives, identifying the impact of social entrepreneurship on organization performance. The result is social entrepreneurship has significant impact on organization performance. It is supported by the financial results which are increasing in the last three years.

The third objectives, identifying the impact of social capital on organization performance, has been fulfilled as significant relationship. The positive result of organization performance such as financial result increment is an indicator of the strength of P-One social capital.

Theoretically, this research contributes to the knowledge on how the entrepreurial orientation of a social entrepreneurs can impact the development of social capital among stakeholders involved in the business, thereby improve the enterprise's performance. Practically, the results of this research can provide a basis for social entreprenuers in improving their organization performance even further.

This research is not without limitation. This research only has one case which resulted on limited samples. To improve the research, next research can enlarge the scope of research, for example, get more disabled organizations/ 
community as research object. Another recommendation is adding more variables to find more accurate factor (s) which can impact on organization performance.

\section{REFERENCES}

Adler, Paul S, and Seok-Woo Kwon. (2002). Social Capital: Prospects For a New Concept. Academy of Management. The Academy of Management Review 27:17-40.

Aida Idris \& Rahayu Hijrah Hati. (2013). Social Entrepreneurship in Indonesia: Lessons from the Past. Journal of Social Entrepreneurship. 4:3,277-301.

Alarifi, G., Robson, P., \& Kromidha, E. (2019). The Manifestation of Entrepreneurial Orientation in the Social Entrepreneurship Context. Journal of Social Entrepreneurship, 10(3), 307-327. doi: 10.1080/19420676.2018.1541015

Austin, J.; Stevenson, H. and Wei-skillern, J. (2006). Social and Commercial Entrepreneurship, Same, Different or Both. Entrepreneurship Theory and Practice. 30 (1):1-22.

Badan Pusat Statistik. (2016). Profil Penduduk Indonesia Hasil Supas 2015, Badan Pusat Statistik. Retrieved from :https://www.bps.go.id/publication/2016/11/30/63daa471092bb2cb7c1fada6/profil-penduduk -indonesia-hasil-supas-2015.html

Bourdieu, P. (1997). The Forms of Capital. In Handbook of Theory of Research for the Sociology of Education. Oxford: Oxford University Press. Pp.47-58.

Bratkovic, T.; Antoncic, B. and Ruzzier, M. (2009). Strategic Utilization of Entrepreneur's Resource-Based Social Capital and Small Firm Growth. Journal of Management and Organization. 15: 486-499.

Cheng, C. N.; Tzeng, L. C.; Ou, W. M. and Chang, K. T. (2007). The Relationship among Social Capital, Entrepreneurial Orientation, Organizational Resources and Entrepreneurial Performance for New Ventures. Contemporary Management Research. 3 (2): 213-232.

Chisholm, A. M. and Nielsen, K. (2009). Social Capital and the Resource-Based View of the Firm. International Studies of Management and Organization. 39 (2): 7-32.

Creswell, J. W. (2005). Educational research: Planning, conducting, and evaluating quantitative and qualitative approaches to research. 2nd ed. Upper Saddle River, NJ: Merrill/Pearson Education

Crossman, A. (2019). What You Need to Understand About Purposive Sampling. Retrieved September 28, 2019, from https://www.thoughtco.com/purposive-sampling-3026727.

Davis, J. L.; Bell, R. G.; Payne, G. T. and Kreiser, P. M. (2010). Entrepreneurial Orientation and Firm Performance: The Moderating Role of Managerial Power. American Journal of Business. 25 (2): 41-54.

Dees, J.G. (2001). The meaning of 'Social Entrepreneurship'. http://www.caseatduke. org/documents/ dees_sedef.pdf.

Diamantidis, A. D., \& Chatzoglou, P. (2019). Factors affecting employee performance: an empirical approach. International Journal of Productivity and Performance Management, 68(1), 171-193. doi: 10.1108/ ijppm-01-2018-0012

Fatoki, O. O. (2011). The Impact of Human, Social and Financial Capital on the Performance of Small and Medium-Sized Enterprises (SMEs) in South Africa. Journal of Social Sciences, 29(3), 193-204. doi: 10.1080/09718923.2011.11892970

Gieles, Emiel, (2017). Performance Measurement Systems for Social Enterprises. Bachelor Thesis. http://arno.uvt.nl/show.cgi?fid=145023 
Vera Andriana Rakhmani, Risa Bhinekawati / The Impact of Entrepreneurial Orientation of Social Entrepreneurship Towards Social Capital and Organization Performance:

A Case Study Of Precious One / 56 - 68

Green, J. C., and V. J. Caracelli, eds. (1997). Advances in mixed-method evaluation: The challenges and benefits of integrating diverse paradigms. In New directions for evaluation, ed. American Evaluation Association. San Francisco: Jossey-Bass.

Green, J. C., V. J. Caracelli, and W. F. Graham. (1989). Toward a conceptual framework for mixed-method evaluation designs. Educational Evaluation and Policy Analysis 11(3):255-74.

Gupta, V. K.; Huang, R. and Yayla, A. A. (2011). Social Capital, Collective Transformational Leadership and Performance: A Resource-Based View of Self-Managed Teams. Journal of Managerial Issues. 23 (1): 31-45.

Hair, J., Hult, G., Ringle, C., \& Sarstedt, M. (2014). A primer on partial least squares structural equation modelling (PLS-SEM) (1sted.). Thousand Oaks: SAGE.

Hair, J., Hult, G., Ringle, C., \& Sarstedt, M. (2017). A primer on partial least squares structural equation modelling (PLS-SEM) (2nd ed.). Los Angeles: SAGE.

Haugh, H. (2005). A research agenda for social entrepreneurship. Social Enterprise Journal, Vol.1 No.1, pp.1-12.

Herman, R. D., \& Renz, D. O. (1999). Theses on Nonprofit Organizational Effectiveness. Nonprofit and Voluntary Sector Quarterly, 28(2), 107-126. doi:10.1177/0899764099282001

Hisrich, R. D., Peters, M. P., \& Shepherd, D. A. (2017). Entrepreneurship (10th ed.). New York, NY: McGrawHill Education.

Ivankova, N. V., Creswell, J. W., \& Stick, S. L. (2006). Using Mixed-Methods Sequential Explanatory Design: From Theory to Practice. Field Methods, 18(1), 3-20.doi: 10.1177/1525822x05282260

Kaplan, R. and Norton, D. (1992). The Balanced Scorecard: Measures that Drive Performance. Harvard Business Review. (January-February): 71-79.

Keeley, B. (2007). OECD insights human capital: how what you know shapes your life. Paris: OECD.

Kirby, J. (2005). Toward a theory of high performance. Harvard Business Review, 83:30-39.

Lumpkin, G. T., \& Dess, G. G. (1996). Clarifying the Entrepreneurial Orientation Construct and Linking It to Performance. The Academy of Management Review, 21(1), 135-172. doi: 10.2307/258632

Mair, J. and Marti, I. (2006). Social Entrepreneurship Research: A Source of Explanation, Prediction and Delight. Journal of World Business. 41 (1):36-44.

McLoughlin, J., Kaminski, J., Sodagar, B., Khan, S., Harris, R., Arnaudo, G. and Mc Brearty, S. (2009), "A strategic approach to social impact measurement of social enterprises", Social Enterprise Journal, Vol. 5 No. 2, pp. 154-178.

Miles, M. B., and A. M. Huberman. (1994). Qualitative data analysis: A sourcebook. 2nd ed. Thousand Oaks, CA: Sage.

Nahapiet, J. and Ghoshal, S. (1998). Social Capital, Intellectual Capital and the Organizational Advantage. Academy of Management Review. 23 (2):242-266.

Norreklit, H. (2000). The Balance on the Balanced Scorecard-a Critical Analysis of some of Its Assumptions. Management Accounting Research. 11:65-88.

OECD. (2001). The well-being of nations the role of human and social capital. Paris.

OECD/ERIA (2018), SME Policy Index: ASEAN 2018: Boosting Competitiveness and Inclusive Growth, SME Policy Index, OECD Publishing, Paris/ERIA, Jakarta, https://doi.org/10.1787/9789264305328-en.

Perreault, C., Brenner, G. A., Menzies, T. V., Filion, L. J., \& Ramangalahy, C. (2007). Social capital and business performance: ethnic enterprises in Canada. International Journal of Business and Globalisation, 1(2), 145. doi: 10.1504/ijbg.2007.014429

Porter, M.E. \& Kramer, M.R. (2011). The big idea: creating shared value. Harvard Business Review, 89(1), 1-17

Putnam, R. D. (1995). Bowling Alone: America's Declining Social Capital. Journal of Democracy. 6 (1): 65-78.

Putnam, R. D., Leonardi, R., \& Nanetti, R. (1993). Making democracy work: civic traditions in modern Italy. Princeton, NJ: Princeton Univ. Press. 
Richard, P. J. (2008). Measuring Organizational as a Dependent Variable: Towards Methodological Best Practice. Journal of Management. 35 (3): 718-804.

Roxas, H. B. and Chadee, D. (2011). A Resource-Based View of Small Export Firms' Social Capital in a Southeast Asian Country. Asian Academy of Management Journal. 16 (2):1-28.

S. Bacq \& F. Janssen (2011): The multiple faces of social entrepreneurship: A review of definitional issues based on geographical and thematic criteria. Entrepreneurship \& Regional Development: An International Journal. 23:5-6,373-403.

Samer, Abu Saifan. (2012). Social Entrepreneurship: Definitions and Boundaries, Technology Innovation Management Review, February 2012:22-27.

Sekaran, U., \& Bougie, R. (2016). Research Methods for Business. New York: Wiley.

Sherman, D. A. (2007). Entrepreneurial Social Sector Organizations: Factors That Facilitate Growth and Performance. Research Paper of the Executive Doctor of Management Program. Case Western Reserve University.

Smerek, R. E. and Denison, D. R. (2007). Social Capital in Organizations: Understanding the Link to Firm Performance. Conference Proceedings of the 2007 Academy of Management(AOM) Annual Conference.

Somers, A. B. (2005). Shaping the balanced scorecard for use in UK social enterprises. Social Enterprise Journal, 1(1), 43-56.

Tashakkori, A., and C. Teddlie. (1998). Mixed methodology: Combining qualitative and quantitative approaches. Applied Social Research Methods Series, vol. 46. Thousand Oaks, CA: Sage.

Tent, D. A. (2015). Social Entrepreneurship. Studia Europaea. 60(4):97-108

Terrell, S. R. (2012). Mixed-Methods Research Methodologies. The Qualitative Report, 17(1), 254-280. Retrieved from https://nsuworks.nova.edu/tqr/vol17/iss1/14

The Law No. 8 Year 2017 Kementerian Hukum dan Hak Asasi Manusia Republik Indonesia

Thedora, A., Rostiana, R., \& Lie, D. (2018). Perbandingan Manajemen Kinerja Karyawan Difabel Pada Usaha Kecil Menengah X Dan Usaha Kecil Menengah Y. Jurnal Muara Ilmu Sosial, Humaniora, Dan Seni, 1(2), 336. doi: 10.24912/jmishumsen.v1i2.909

Thompson, J. L. (2008). Social enterprise and social entrepreneurship: where have we reached? Social Enterprise Journal, 4(2),149-161. doi: 10.1108/17508610810902039

Tripp, G., Payne, M., and Diodorus, D. (2009). Social Capital. New York: Nova Science Publishers.

Trivedi, C. (2010). A Social Entrepreneurship Bibliography. The Journal of Entrepreneurship, 19 (1), 81-85.

Vogt, W Paul, Johnson, R. Burke (2011) Dictionary of Statistics and Methodology: A Nontechnical Guide for the Social Sciences. London: Sage.

Westlund, H. (2006). Social Capital in the knowledge economy: theory and empirics. Berlin: Springer.

Westlund, Hans \& Gawell, Malin. (2012). Building Social Capital for Social Entrepreneurship. Annals of Public and Cooperative Economics. 83.101-116.10.1111/j.1467-8292.2011.00456.x.

Wood C., \& Leighton D., (2010), Measuring Social Value: The Gap Between Policy and Practice. London, UK: Demos.

Woolcock, M. (1998). Social Capital and Economic Development: Toward a Theoretical Synthesis and Policy Framework. Theory and Society. 27:151-208.

Yang, C.-L., Huang, R.-H., \& Lee, Y.-C. (2014). Building a Performance Assessment Model for Social EnterprisesViews on Social Value Creation. Science Journal of Business and Management, 2(1), 1. doi: 10.11648/j.sjbm.20140201.11

Zahra, S. A., Rawhouser, H. N., Bhawe, N., Neubaum, D. O., \& Hayton, J. C. (2008). Globalization of social entrepreneurship opportunities. Strategic Entrepreneurship Journal, 2 (2), 117-131. doi: $10.1002 /$ sej.43 